\title{
Can we predict groundwater discharge from terrestrial ecosystems using existing eco-hydrological concepts?
}

\author{
A. P. O'Grady ${ }^{1}$, J. L. Carter ${ }^{2}$, and J. Bruce ${ }^{1}$ \\ ${ }^{1}$ Water for a Healthy Country National Research Flagship, CSIRO Ecosystem Sciences Private Bag 12, Hobart, \\ Tasmania 7001, Australia \\ ${ }^{2}$ Water for a Healthy Country National Research Flagship, CSIRO Ecosystem Sciences Private Bag 5, Wembley, \\ WA 6913, Australia
}

Received: 11 August 2011 - Published in Hydrol. Earth Syst. Sci. Discuss.: 31 August 2011

Revised: 22 November 2011 - Accepted: 2 December 2011 - Published: 15 December 2011

\begin{abstract}
There is increasing recognition of the role that groundwater plays in the maintenance of ecosystem structure and function. As a result, water resources planners need to develop an understanding of the water requirements for these ecosystems. In this study we reviewed estimates of groundwater discharge from terrestrial vegetation communities around Australia and explored this data set for empirical relationships that could be used to predict groundwater discharge in data poor areas. In particular we explored how leaf area index and the water balance of groundwater systems conformed to two existing ecohydrological frameworks; the Budyko framework, which describes the partitioning of rainfall into evapotranspiration and runoff within a simple supply and demand framework, and Eagleson's theory of ecological optimality. We demonstrate strong convergence with the predictions of both frameworks. Terrestrial groundwater systems discharging groundwater lie above the water limit line as defined in the Budyko framework. However, when climate wetness was recalculated to include groundwater discharge there was remarkable convergence of these sites along this water limit line. Thus, we found that there was a strong correlation between estimates of evapotranspiration derived from the Budyko's relationship with observed estimates of evapotranspiration. Similarly, the LAI of ecosystems with access to groundwater have higher LAI than those without access to groundwater, for a given climatic regime. However, again when discharge was included in the calculation of climate
\end{abstract}

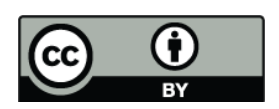

Correspondence to: A. P. O'Grady (anthony.ogrady@csiro.au) wetness index there was again strong convergence between the two systems, providing support for ecological optimality frameworks that maximize LAI under given water availability regimes. The simplicity and utility of these simple ecohydrological insights potentially provide a valuable tool for predicting groundwater discharge from terrestrial ecosystems, especially in data poor areas.

\section{Introduction}

Applying the definition proposed by Budyko (1974), the Australian landscape is predominantly water-limited. Evaporation exceeds rainfall across most of the continent (Donohue et al., 2009). As a result, there has been considerable focus on understanding the water balance in Australian landscapes, driven by a motivation to ensure that this valuable and limiting resource is used sustainably and that sufficient water resources are allocated for the maintenance and protection of key environmental assets and services. In recent years there has been increasing recognition of the role that groundwater plays in the maintenance of ecosystem structure and function (Eamus and Froend, 2006). Groundwater use has been demonstrated in a range of terrestrial vegetation communities around Australia including woodlands in Mediterranean environments (Groom, 2000), riparian ecosystems (Thorburn et al., 1993; Lamontagne et al., 2005), temperate plantations (Benyon et al., 2006), tropical and arid woodlands and tropical forests (Drake and Franks, 2003; O'Grady et al., 2006, 2009). Recognition of the importance of this water resource to vegetation functioning imposes an imperative on water

Published by Copernicus Publications on behalf of the European Geosciences Union. 
resources managers to account for these environmental water requirements within their water allocation plans. However, the capacity to do so is significantly constrained by a lack of detailed information on extent of groundwater dependence.

The close coupling between ecosystem productivity and water balance is well recognised (Specht and Morgan, 1981; Specht, 1983; Eamus, 2003; Huxman et al., 2004; Liu, 2009). In a review of this topic, Eamus (2003) demonstrated that above ground biomass and the productivity of fine tissues (roots and leaves) increased asymptotically with rainfall and that the net annual increment (a common measure of forest productivity) in Eucalyptus globulus (Labill.) plantations increased as an asymptotic function of rainfall and potential evapotranspiration. Specht (1972), Specht and Morgan (1981) and Specht (1983) demonstrated that foliage cover in the overstorey of perennial plant communities was linearly related to the ratio of actual evapotranspiration and potential evaporation $\left(E_{\mathrm{a}} / E_{0}\right)$. The relationship proposed by Specht (1972) is conceptually similar to the water balance framework of Budyko (1974), and as such provides insights into the link between productivity of ecosystems and the water balance. Budyko (1974) analysed catchment runoff and developed a relationship that partitions average annual rainfall into average annual runoff and evapotranspiration using a simple supply and demand framework. The resultant relationship, known as the "Budyko curve" has become an enduring hydrological relationship (Donohue et al., $2007)$, that describes variation in the $E_{\mathrm{a}} / E_{0}$ ratio in relation to changes in climatic water availability, summarised as the ratio of $P / E_{0}$ (see Zhang et al., 2004 or Donohue et al., 2007 for more detail). Recently, Donohue et al. (2007) argued that explicit consideration of vegetation dynamics within the Budyko framework could potentially increase the utility of this framework for addressing land management and water resources planning issues.

Leaf area index (LAI), defined as the projected leaf area $\left(\mathrm{m}^{2}\right)$ per unit ground area $\left(\mathrm{m}^{2}\right)$, is a useful parameter for examining the linkage between vegetation dynamics and the water balance as it is the main determinant of light interception and hence the productivity and water use of ecosystems (Landsberg and Waring, 1997; Donohue et al., 2007; White et al., 2010). It has been demonstrated that LAI varies in response to water availability at a range of spatial and temporal scales (Grier and Running, 1977; Battaglia et al., 1998; Carter and White, 2009; White et al., 2010). However, incorporation of these observations into a sound predictive ecohydrological framework remains problematic. In an attempt to do so, the theory of ecological optimality (Eagleson, 1978, 1982) states that in water-limited environments, ecosystems evolve in a manner such that over short time scales (i.e. one to a few generations), canopy density (analogous to LAI), will equilibrate with the climate and soil to the value at which equilibrium soil moisture will be maximised. At longer time scales (i.e. over many generations), species will be selected whose potential transpiration efficiency results in the maximum equilibrium soil moisture and over evolutionary time scales, vegetation will alter soil physical properties towards equilibrium values which maximises canopy density (Eagleson, 1982; Eagleson and Tellers, 1982; Hatton et al., 1997). The framework predicts a close coupling between canopy structure and water availability. Although, Kerkhoff et al. (2004) criticised the ecological optimality theory as proposed, in particular the assumption that soil water availability would be maximised, it has also been argued that ecological optimality potentially provides a useful underpinning framework for the emerging field of ecohydrology (Hatton et al., 1997).

In support of ecological optimality, Ellis and Hatton (2008) demonstrated that across southern Australia, there was a strong linear relationship between LAI and rainfall. Correlations between LAI and a range of climate indices have been previously demonstrated for other ecosystems (Grier and Running, 1977; Nemani and Running, 1989; Baldocchi and Meyers, 1998). Furthermore, Macfarlane et al. (2010) recently demonstrated that understorey LAI increased rapidly in response to thinning of the overstorey canopy, so that community LAI was maintained at a level consistent with the predictions from ecohydrological optimality. In these previous studies it has been implicit that rainfall is the major source of water for evapotranspiration. However, access to groundwater potentially provides additional and more temporally reliable water for terrestrial communities and it is often assumed that this would result in increased leaf area index and productivity, although this assumption has not been explicitly tested.

In this paper we have examined the relationships between LAI, climate and the water balance of ecosystems dependent on groundwater. Specifically we ask the question; can existing ecohydrological concepts be used to estimate groundwater discharge in terrestrial vegetation communities? In particular, we hypothesised that the LAI of terrestrial ecosystems with access to groundwater would be higher than that of terrestrial ecosystems without access to groundwater for any given climatic regime and that the increase in LAI would be proportional to the volume of water accessed from groundwater. In addition to this, we expected that ET from these communities would be higher, but this increase would still be broadly consistent with existing theoretical water balance frameworks such as the Budyko relationship that describes the relationship of ET with potential evaporation as a function of incoming energy and water availability. To explore these hypotheses we analysed published water balance studies that have identified groundwater discharge through the system and examined relationships between the volume of groundwater discharged and the existing ecological and climatic regimes. 


\section{Methods}

We analysed existing Australian water balance studies that identified groundwater discharge as a component of evapotranspiration. The water balance of a site can be described as:

$Q_{\mathrm{wt}}=P-(I+E+T)-\Delta S_{\mathrm{w}}$

Where $Q_{\mathrm{wt}}=$ net water balance (drainage $+\mathrm{ve}$, discharge - ve), $P=$ rainfall, $I=$ rainfall interception losses (i.e. direct evaporation from the canopy and stem, usually estimated as the difference between rainfall and throughfall), $E=$ evaporative losses from the soil surface (usually measured with mini lysimeters), $T=$ transpiration (measured directly e.g. using sapflow techniques) and $\Delta S_{\mathrm{w}}$ is the change in the volumetric soil water content between two time periods (Benyon et al., 2006). All the studies included in this review were plot scale water balance studies, conducted for a period of at least 12 months, where evapotranspiration was calculated as the sum of $E, T$ and $I$.

Ellis and Hatton (2008) reviewed relationships between LAI and climatic variables including rainfall and evaporation for southern Australia. In this paper, we extend their analysis and include more recent measurements of LAI, therefore characterising this relationship over a broader range of climatic conditions. Leaf area index of the various communities was estimated using a range of techniques including visual estimation, light interception techniques such as canopy photography or the LAI 2000 plant canopy analyser (Licor Lincoln, USA) or via allometric equations between leaf area and plant size (generally stem diameter) developed during destructive harvesting.

To assess the effect of groundwater access on the relationship between climate and LAI, we compared the slope and intercept of the linear relationships between Climate Wetness Index (CWI, the ratio of annual rainfall to potential evaporation) and LAI, observed by Ellis and Hatton (2008) to; (i) quantify the relationship between CWI and LAI for the water balance studies that identified groundwater discharge reviewed here, and (ii) to examine the relationship between LAI and a modified CWI that accounts for additional water available from groundwater:

$\mathrm{CWI}_{\mathrm{g}}=\frac{(P+g)}{E_{0}}$

Where $\mathrm{CWI}_{\mathrm{g}}=$ is the dimensionless climate wetness index that includes the groundwater component, $P=$ total precipitation $(\mathrm{mm}), g=$ groundwater discharge $(\mathrm{mm})$ and $E_{0}=$ potential evaporation $(\mathrm{mm})$.

In evaluation of Budyko's framework, long-term steady state evapotranspiration from a catchment can be described by the relationship between two climatic variables, precipitation $(P)$ and the evaporative demand $\left(E_{0}\right)$ :

$$
\frac{E}{E_{0}}=1+\frac{P}{E_{0}}-\left[1+\left(\frac{P}{E_{0}}\right)^{\mathrm{w}}\right]^{1 / \mathrm{w}}
$$

Where $w$ is a parameter that describes the shape of the function between $E_{\mathrm{a}} / E_{0}$ and CWI and is related to catchment properties (Zhang et al., 2004). Ecosystems discharging groundwater have access to water other than rainfall, thus in order to compare the groundwater discharge sites to the Zhang et al. (2004) formulation of ET (Eq. 3) we have included groundwater discharge and recalculated ET such that:

$$
\frac{E}{E_{0}}=1+\frac{P_{+\mathrm{gw}}}{E_{0}}-\left[1+\left(\frac{P_{+\mathrm{gw}}}{E_{0}}\right)^{\mathrm{w}}\right]^{1 / \mathrm{w}}
$$

Where $P_{+\mathrm{gw}}$ is rainfall plus the terrestrial groundwater discharge component $(\mathrm{mm})$.

We used a group regressions procedure to compare the relationships between LAI and $P / E_{0}$ as described by Ellis and Hatton (2008) with the LAI of systems with access to groundwater. The program SMATR (Warton et al., 2006) was used to compare the slopes and intercepts of these relationships. Ordinary least squares regression was used to compare observed ET with estimates of ET predicted using the reformulated Zhang et al. (2004) equation (Eq. 4).

\section{Results}

We identified 17 water balance studies that included measured ET (with a recognised groundwater discharge component) and LAI and a further six where no groundwater discharge was identified. These latter sites were included for comparative purposes. In total, 31 estimates of groundwater discharge are included in this analysis (Table 1). The vegetation studied included plantations, trees belts, native forests and the riparian forests associated with the Chowilla floodplain on the Murray River in South Australia. The majority of sites were restricted to southern Australia, and in particular South Australia and Western Australia (Fig. 1). Estimated rates of groundwater discharge varied from $2 \mathrm{~mm} \mathrm{yr}^{-1}$ to more than $700 \mathrm{~mm} \mathrm{yr}^{-1}$ and ranged from less than $1 \%$ to $100 \%$ of the measured evapotranspiration.

Actual to potential evapotranspiration ratios $\left(E_{\mathrm{a}} / E_{0}\right)$ for the plot scale water balance studies varied from less than 0.05 to approximately 1.6 (Table 1 ). Climate wetness indices varied from very arid environments $(\mathrm{CWI}<0.05)$ to the very wet environments $(\mathrm{CWI}>7)$. The relations between $E_{\mathrm{a}} / E_{0}$ and CWI of these plot scale studies were conceptually consistent with the Budyko framework, i.e. at water limited sites $E_{\mathrm{a}} / E_{0}$ increased linearly and reached a plateau at a CWI of 1 . Actual $E_{\mathrm{a}} / E_{0}$ ratios of sites with access to groundwater fell above the water limitation line as defined by the Budyko framework (Fig. 2a). However, when the CWI was recalculated to include the discharge of groundwater, i.e. $(P+g) / E_{0}$ most sites fell along the water limit line defined by the Budyko framework (Fig. 2b). Two outliers were identified and the causes for this are difficult to attribute. However, these two points are tree belts. Thus LAI and ET are particularly sensitive to the area over which these 


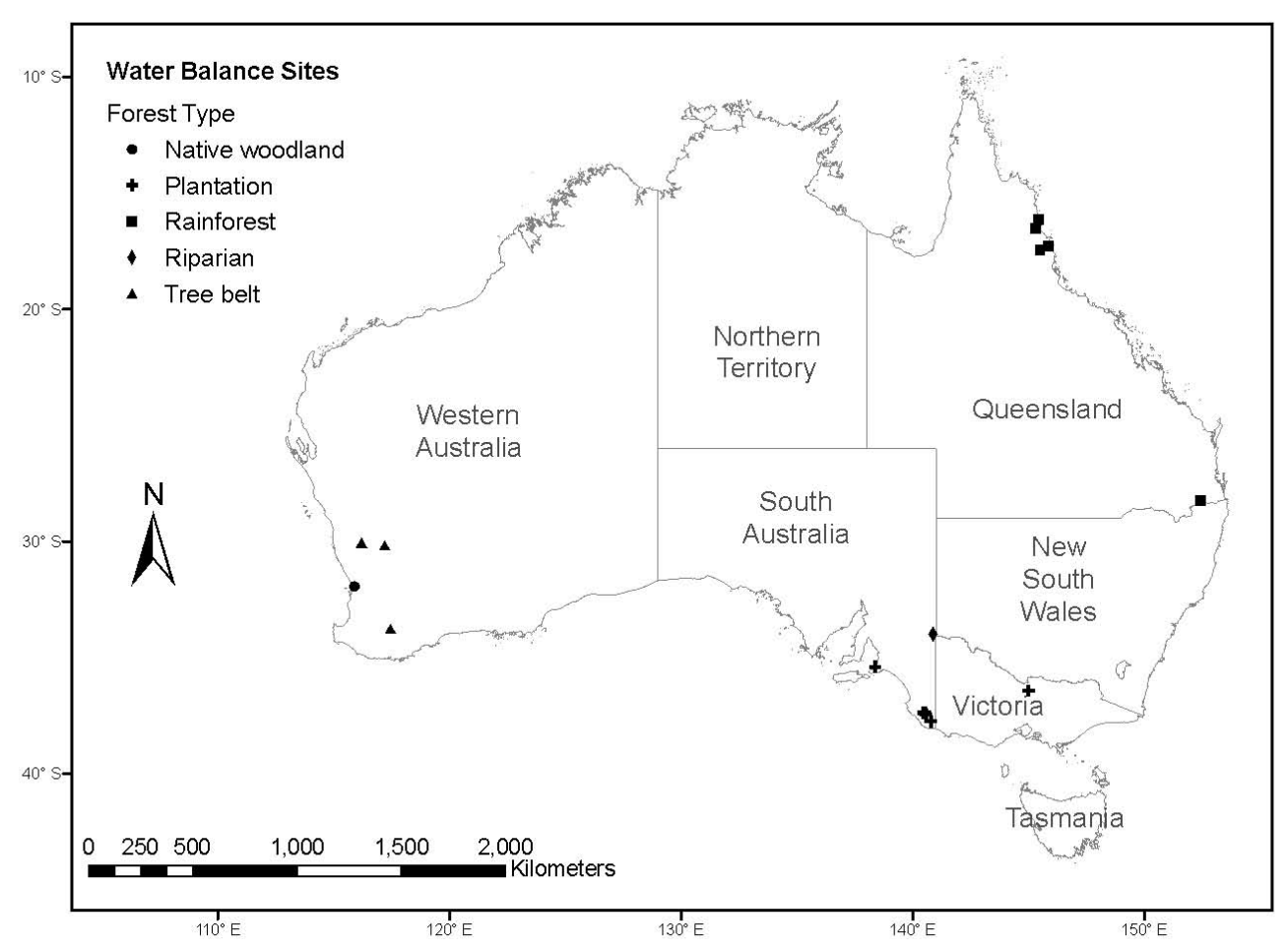

Fig. 1. Location of sites in Australia used in the analysis of the relationship between climate, LAI and groundwater discharge.

numbers are calculated. Similarly, there was a strong and highly significant $\left(r^{2}=0.79\right.$, df $\left.1,30, P<0.001\right)$ linear correlation between estimates of ET derived using the Budyko equation with discharge included and observed estimates of ET derived from water balance studies (Fig. 3).

Leaf area index data were collated from a range of sites around the country. These estimates varied from 0.2 for overstorey LAI in the Banskia communities of south west Western Australia to approximately 5 for sub-tropical rainforest communities in south east Queensland (Table 1). Of the studies identified, not all sites had access to groundwater. However, at all sites detailed plot scale water balance measurements were undertaken. Actual ET ranged from $73 \mathrm{~mm} \mathrm{yr}^{-1}$ to approximately $1900 \mathrm{~mm} \mathrm{yr}^{-1}$. There was a linear increase in LAI with increasing CWI up to a value of 1 , after which there was a marked plateau (Fig. 4a). Thus for water limited sites there was a strong linear relationship between LAI and the ratio $E_{\mathrm{a}} / E_{0}$ (Fig. 4b).

At sites with access to groundwater there was a significant linear relationship between LAI and CWI (Fig. 4a; LAI and CWI, LAI $=3.606(\mathrm{CWI})+0.883, r^{2}=0.48, \quad \mathrm{df}=17$, $p=0.001)$. However, this relationship was more variable than that reported by Ellis and Hatton (2008). There was no significant difference between the slope of the relationship between LAI and CWI for sites with access to groundwater and the relationship reported by Ellis and Hatton (2008). However, there was a significant difference in the $Y$-intercept (Fig. 5a, $p<0.001$ ). Sites having access to groundwater had a higher $Y$-intercept than that reported by Ellis and Hatton (2008). When the CWI was recalculated to incorporate the groundwater discharge component, the differences between the $Y$-intercepts were significantly reduced, although a small but significant $(P=0.0499)$ difference remained. Despite this, the correlation between CWI and LAI increased from $r^{2}=0.5$ to $r^{2}=0.7$ and the RMSE associated with the regression reduced from 0.85 to 0.66 (Fig. $5 b$ ).

\section{Discussion}

A major limitation to sustainable water resources planning is the lack of reliable estimates of the various components of the water balance. Within Australia estimates of groundwater discharge are relatively few. In contrast, recharge is commonly estimated; a recent paper by Crosbie et al. (2010) reviewed over 4000 estimates of recharge across Australia. Furthermore, although it has long been recognised that the LAI of terrestrial plant communities is strongly related to climate and indices of water availability (Specht, 1972; Baldocchi and Meyers, 1998; Eamus et al., 2001; Ellis and Hatton, 2008), these insights have not been incorporated into water resources planning, neither have these indices recognised that groundwater may provide a water source other than rainfall for evapotranspiration.

In the current analysis we identified strong convergence between terrestrial vegetation communities that have access to groundwater with existing ecohydrological concepts, 
Table 1. Summary of Australian water balance studies that identified groundwater discharge used in the analysis of leaf area index and groundwater discharge relationships.

\begin{tabular}{|c|c|c|c|c|c|c|c|c|c|c|c|}
\hline State & Latitude & Longitude & $\begin{array}{l}\text { Forest } \\
\text { type }\end{array}$ & $\begin{array}{r}\text { Precipi- } \\
\text { tation } \\
\left(\mathrm{mm} \mathrm{yr}^{-1}\right)\end{array}$ & $\begin{array}{r}E_{0} \\
(\mathrm{~mm} \\
\left.\mathrm{yr}^{-1}\right)\end{array}$ & $\begin{array}{l}E_{0} \\
\text { Type }\end{array}$ & LAI & $\begin{array}{r}\text { Groundwater } \\
\text { discharge } \\
(\mathrm{mm})\end{array}$ & $\begin{array}{r}\text { ET (obs., } \\
\mathrm{mm} \\
\left.\mathrm{yr}^{-1}\right)\end{array}$ & $\begin{array}{l}E_{\mathrm{a}} / \\
E_{0}\end{array}$ & Reference \\
\hline SA & -37.37 & 140.46 & plantation & 713 & 980 & Areal & 3.5 & 2 & 713 & 0.73 & Benyon (2004) \\
\hline SA & -35.23 & 138.22 & plantation & 838 & 1409 & Pan & 2.7 & 52 & 936 & 0.66 & Holland and Benyon (2011) \\
\hline SA & -33.98 & 140.87 & riparian & 262 & 2000 & Pan & 1.0 & 55 & 73 & 0.04 & Thorburn et al. (1993) \\
\hline SA & -33.98 & 140.87 & riparian & 261 & 2000 & Pan & 1.0 & 73 & 73 & 0.04 & Thorburn et al. (1993) \\
\hline SA & -33.98 & 140.87 & riparian & 260 & 2000 & Pan & 0.6 & 94 & 110 & 0.06 & Thorburn et al. (1993) \\
\hline SA & -37.43 & 140.57 & plantation & 740 & 970 & Areal & 3.5 & 107 & 847 & 0.87 & Benyon (2004) \\
\hline SA & -37.37 & 140.46 & plantation & 713 & 980 & Areal & 3.7 & 226 & 904 & 0.92 & Benyon (2004) \\
\hline SA & -37.43 & 140.57 & plantation & 666 & 1250 & Point & 3.7 & 413 & 1059 & 0.85 & Benyon (2004) \\
\hline SA & -37.36 & 140.53 & plantation & 713 & 1230 & Point & 4.1 & 440 & 1158 & 0.94 & Benyon (2004) \\
\hline SA & -33.98 & 140.87 & riparian & 263 & 2000 & Pan & 1.5 & 502 & 730 & 0.37 & Thorburn et al. (1993) \\
\hline SA & -37.74 & 140.78 & plantation & 567 & 1180 & Point & 3.1 & 636 & 1193 & 1.01 & Benyon (2004) \\
\hline SA & -34.44 & 140.6 & Native woodland & 268 & 1980 & Pan & & 48 & 195 & 0.10 & Doody et al. (2009) \\
\hline SA & -34.44 & 140.6 & Native woodland & 268 & 1980 & Pan & & 70 & 216 & 0.11 & Doody et al. (2009) \\
\hline SA & -34.44 & 140.6 & Native woodland & 268 & 1980 & Pan & & 315 & 320 & 0.16 & Doody et al. (2009) \\
\hline SA & & & Plantation & 633 & 1124 & Penman Monteith & & 116 & 712 & 0.63 & Benyon et al. (2006) \\
\hline SA & & & Plantation & 747 & 1230 & Point & & 561 & 1343 & 1.09 & Benyon et al. (2006) \\
\hline SA & & & Plantation & 362 & 1340 & Penman Monteith & & 671 & 1074 & 0.8 & Benyon et al. (2006) \\
\hline Vic & -36.25 & 145.00 & Plantation & 480 & 1350 & Pan & 2.1 & 173 & 413 & 0.31 & Morris and Collopy (1999) \\
\hline Vic & & & Plantation & 480 & 1350 & Pan & & 221 & 459 & 0.34 & Morris and Collopy (1999) \\
\hline NSW & & & Tree belt & 627 & 1385 & Pan & & 22 & 726 & 0.52 & Crosbie et al. (2007) \\
\hline NSW & -35.2 & 145.11 & Plantation & 619 & 1280 & Penman Monteith & & 733 & 1277 & 0.99 & Benyon et al. (2006) \\
\hline NSW & -35.5 & 145 & Plantation & 664 & 1220 & Penman Monteith & & 377 & 928 & 0.76 & Benyon et al. (2006) \\
\hline WA & -33.45 & 117.27 & Tree belt & 483 & 1350 & Priestly Taylor & 2.5 & 150 & 595 & 0.44 & White et al. (2002) \\
\hline WA & -30.04 & 116.21 & Tree belt & 380 & 1691 & Priestly Taylor & 2.7 & 420 & 1539 & 0.91 & Carter and White (2011) \\
\hline WA & -30.04 & 116.21 & Tree belt & 380 & 1690 & Priestly Taylor & 2.7 & 515 & 1539 & 0.91 & Carter and White (2011) \\
\hline WA & -30.09 & 117.12 & Tree belt & 319 & 2200 & Pan & 1.1 & 30 & 274 & 0.12 & Wildy et al. (2004) \\
\hline WA & -30.09 & 117.12 & Tree belt & 319 & 2200 & Pan & 2.2 & 218 & 391 & 0.18 & Wildy et al. (2004) \\
\hline WA & & & Native woodland & 750 & 1843 & Pan & & 64 & 635 & 0.34 & Dodd and Bell (1993) \\
\hline WA & & & Native woodland & 772 & 1843 & Pan & & 67 & 814 & 0.44 & Farrington et al. (1990) \\
\hline WA & -31.55 & 115.41 & Native woodland & 772 & 1843 & Pan & 0.2 & 0 & 666 & 0.36 & Farrington et al. (1989) \\
\hline QLD & -17.16 & 145.51 & Rainforest & 8100 & 1073 & Penman & 3.3 & 0 & 971 & 0.90 & McJannet et al. (2007) \\
\hline QLD & -17.27 & 145.29 & Rainforest & 2983 & 1237 & Penman & 4.1 & 0 & 1518 & 1.23 & McJannet et al. (2007) \\
\hline QLD & -16.08 & 145.26 & Rainforest & 3952 & 1269 & Penman & 4.2 & 0 & 1298 & 1.02 & McJannet et al. (2007) \\
\hline QLD & -16.31 & 145.16 & Rainforest & 3040 & 982 & Penman & 4.5 & 0 & 1533 & 1.56 & McJannet et al. (2007) \\
\hline QLD & -28.13 & 152.25 & Rainforest & 1350 & 1566 & Priestly Taylor & 5.0 & 0 & 1259 & 0.80 & Hutley et al. (1997) \\
\hline NT & & & Riparian & 1157 & 2300 & Pan & & 143 & 1300 & 0.57 & O'Grady et al. (2002) \\
\hline
\end{tabular}

particularly the Budyko framework. The Budyko framework inherently incorporates the biophysical controls on evaporation (Donohue et al., 2007; Zhang et al., 2008), thus it is not surprising that the strong convergence identified here exists. However, it is worth recognising two factors:

Firstly, the strength of convergence with the Budyko framework identified in Figs. 2 and 3 was somewhat surprising given that the data collated were plot-based water balance studies, where estimates of evapotranspiration were constructed from bottom-up measurements of transpiration, interception and understory evaporation. Furthermore, these plot based studies were conducted over relatively short time intervals, typically 1 to $2 \mathrm{yr}$. In contrast, the Budyko framework was developed from the compilation of catchment based-studies and represents steady state conditions that are unlikely to apply over the short-term, particularly the underlying assumption that changes in soil water content are minimal. Secondly, a priori, for systems that have access to groundwater, we expected $E_{\mathrm{a}} / E_{0}$ ratios to converge along the energy-limit line of the Budyko framework, i.e. that evapotranspiration of systems with access to groundwater would be constrained by the amount of incoming energy. In contrast, when the groundwater component was included (Eq. 3), there was strong convergence with Budyko's theoretical water-limit line (Fig. 2b).

It is difficult to fully attribute this response, but there may be several explanations for this observation. In the studies analysed, groundwater salinities varied from $1 \mathrm{dSm}^{-1}$ to more than $60 \mathrm{dSm}^{-1}$. Thus, groundwater may be thermodynamically less available due to its higher osmotic concentration than either rainfall or soil water. Furthermore, in water-limited areas typical of the sites analysed in this paper, high vapour pressure deficits can significantly constrain stomatal conductance and water use (O'Grady et al., 2009) and root distributions tend to be exponentially distributed throughout the soil profile (e.g. O'Grady et al., 2005). Thus not all of the water that is lost via evapotranspiration is derived from groundwater. Furthermore, the hydraulic architecture of plants adapted to arid and semi-arid environments can limit ET (Eamus et al., 2000; Do et al., 2008). Thus, 

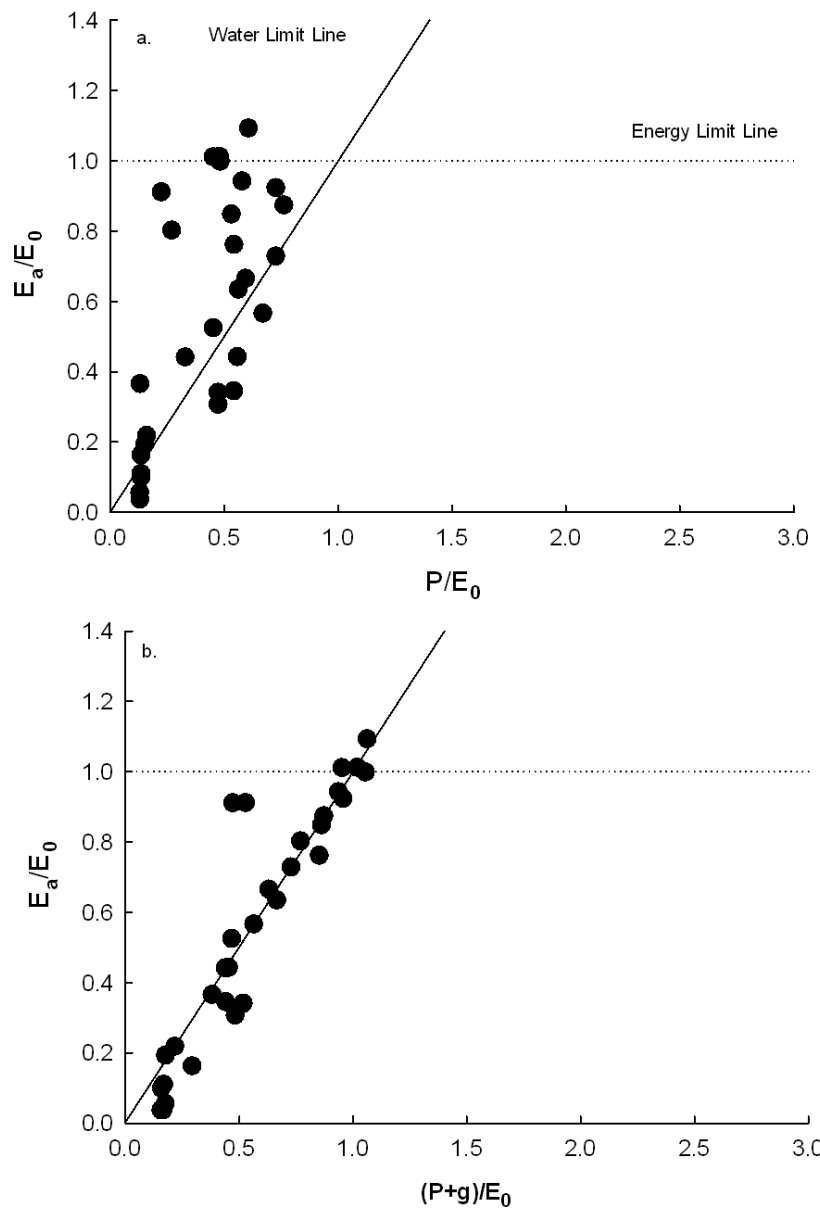

Fig. 2. (a) Relationship between measured $E_{\mathrm{a}} / E_{0}$ and climate wettness index $\left(\mathrm{CWI}=P / E_{0}\right)$ for sites with access to groundwater. (b) Relationship between $E_{\mathrm{a}} / E_{0}$ and a recomputed climated wetness index that includes groundwater discharge where: $\mathrm{CWI}=(P+$ $g) / E_{0}$ (Eq. 2).

despite having access to groundwater, it appears that these communities remain water-limited.

Leaf area index was strongly related to climate and water availability, as has been observed in previous studies (e.g. Ellis et al., 2005; Ellis and Hatton, 2008). Leaf area index of communities with access to groundwater increased linearly with CWI and there was strong evidence of convergence with the predictions of the Budyko framework. Leaf area index appears to plateau at a CWI $>1$ (Fig. 4a), although we acknowledge that there are very few estimates of LAI above a CWI of 1. This in itself it not surprising and highlights the important role of LAI in intercepting incoming energy and partitioning this energy into fluxes of latent and sensible energy (Landsberg and Waring, 1997; Baldocchi and Meyers, 1998). A linear relationship between $E_{\mathrm{a}} / E_{0}$ and foliage projective cover, a surrogate of LAI, in water-limited environments has been previously recognised (Specht, 1972). Similarly, Ellis and Hatton (2008) demonstrated a strong linear

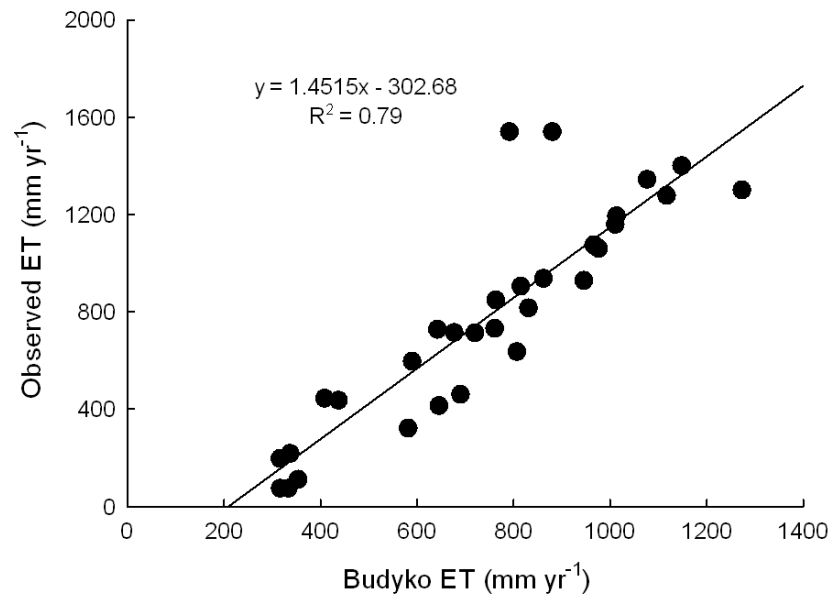

Fig. 3. Relationship between observed ET and ET calculated using the Zhang et al. (2004) version of the Budyko equation modified to include groundwater discharge (calculated using $w=5$, Eq. 4).

relationship between rainfall and LAI. The direct correlation between rainfall and LAI alone is useful, but further insights into the water balance of a system are gained by including the evaporative environment, as this directly relates to water availability in the system. Here we have demonstrated that $E_{\mathrm{a}} / E_{0}$ is indeed linearly related to LAI over a wide range of climatic conditions (Fig. 4b). Ratios of $E_{\mathrm{a}} / E_{0}$ larger than one reported in the literature are difficult to reconcile. For example, McJannet et al. (2007) reported actual evapotranspiration 1.6 times higher than Penman evaporation for high altitude rainforests in north Queensland. They attributed this to large amounts of advected energy in these mountainous systems situated next to the coast. However, this may also reflect errors in water balance measurements. Despite this, the strong linear agreement over the water-limited spectrum of the relationship provides a simple and powerful empirical method for estimating LAI and ET of terrestrial plant communities.

As hypothesised, the LAI of communities with access to groundwater was higher at any given CWI than that predicted by Ellis and Hatton (2008). One qualification of this statement is that detailed water balance data were not available for the sites presented in the Ellis and Hatton (2008) review. As a result we cannot unequivocally say that none of the sites included in the Ellis and Hatton (2008) review had access to groundwater. Despite this, there were significant differences in the $Y$-intercept of the slopes of the relationships for sites with access to groundwater and that reported in the Ellis and Hatton (2008) review. When the groundwater discharge component was included in the CWI there was a significant convergence between these two relationships, although a slight but significant $(P=0.0499)$ difference in intercept between the two remained. It is difficult to determine whether this difference in the $Y$ intercept is real or an 

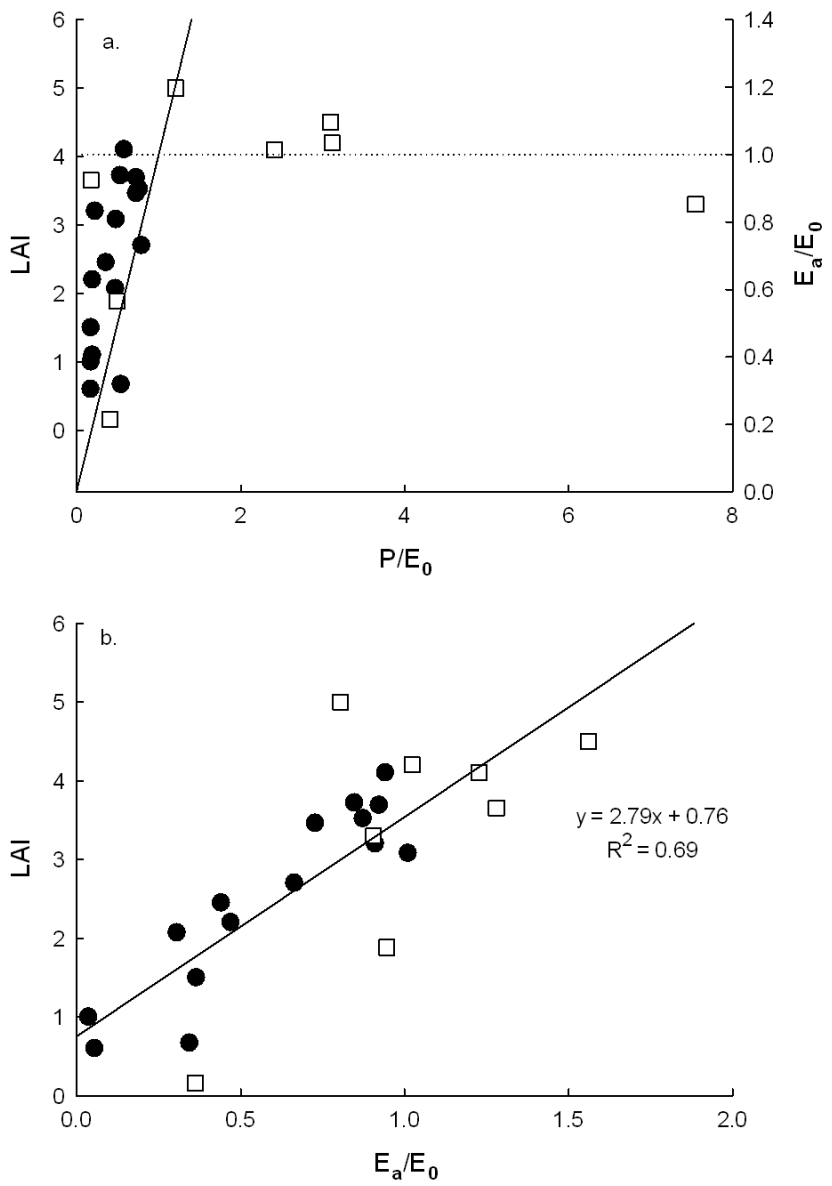

Fig. 4. (a) Relationship between climate wetness index and leaf area index for sites with access to groundwater (solid symbols) and sites without access to groundwater (open symbols). (b) Relationship between the ratio of actual evapotranspiration and potential transpiration to leaf area index for sites with and without access to groundwater.

artefact of the low degrees of freedom in the relationship in this analysis. Either way, this finding does raise the possibility that groundwater discharge from terrestrial ecosystems could be estimated directly using simple empirical models of climate, calibrated using community LAI.

Terrestrial groundwater discharge is a component of the water balance that is often overlooked in water resources planning. Partly this reflects the difficulty and expense associated with quantifying this water balance term. The simple ecohydrological relationships observed in this analysis, provide valuable tools for estimating discharge in terrestrial ecosystems at large spatial scales as they use insights based on a sound conceptual frameworks (e.g. the Budyko framework) and highlights the value of incorporating biological responses into hydrological frameworks (Donohue et al., 2007). Here have demonstrated a clear increase in the LAI of terrestrial vegetation in response to groundwater access. This observation provides a tool for estimating groundwa-
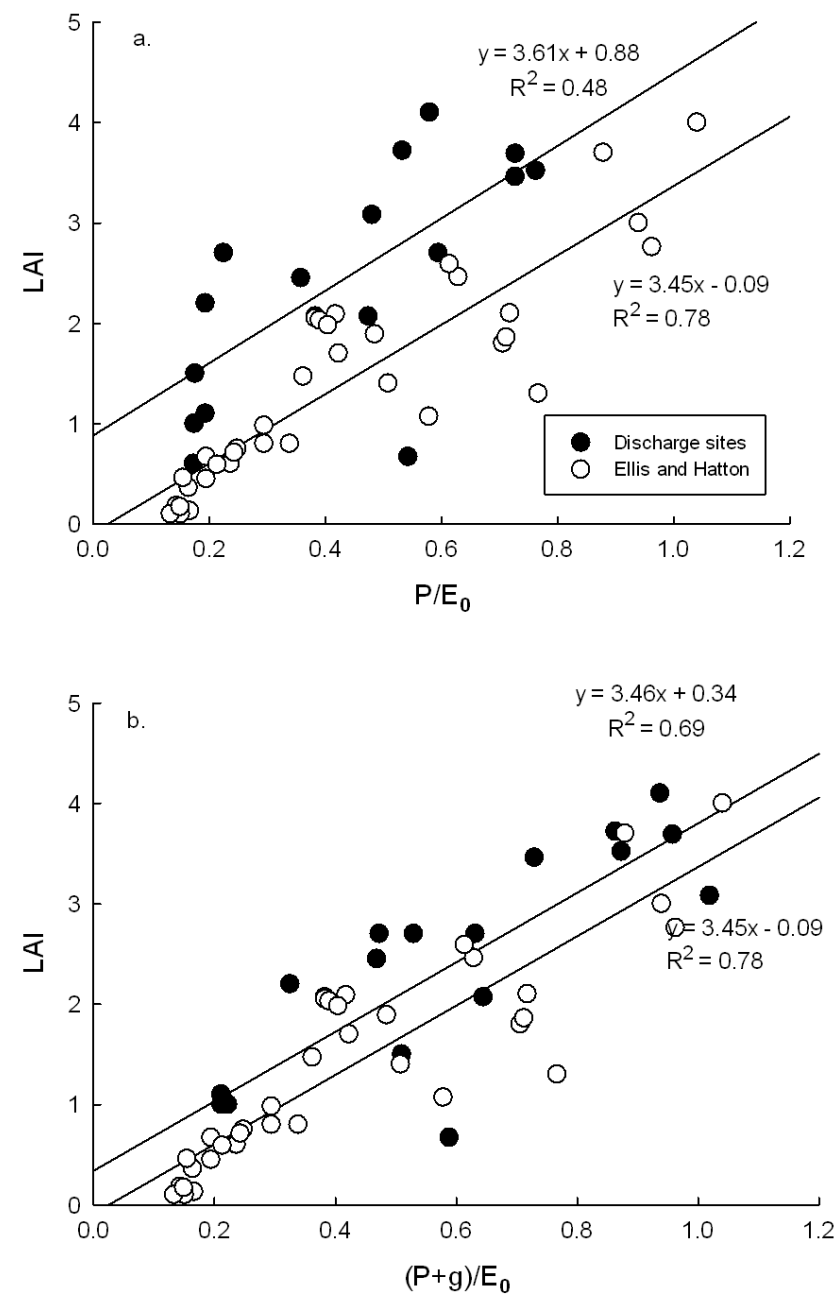

Fig. 5. (a) Relationship between climate wetness index and leaf area index for sites identified as having groundwater dischage as a component of evapotranspiration compared to the Ellis and Hatton (2008) relationship. (b) Demonstrates the convergence between the two relationships when the CWI is recalculated to include the groundwater discharge component $\left(\mathrm{CWI}=(P+g) / E_{0}\right.$, Eq. 2$)$.

ter discharge where groundwater discharge can be estimated as the difference in water required to attain a given LAI for a known climate wetness index. These ecohydrological approaches may be particularly useful in data poor areas, or in areas where detailed investigations of the water balance are not warranted. Many of the required inputs for these types of analyses are available from remotely sensed data, e.g. actual evapotranspiration (Guerschman et al., 2009), evaporation (Donohue et al., 2010) and LAI (Hill et al., 2006) and while questions may remain about the accuracy of some remotely sensed products, these will inevitably improve over time.

Acknowledgements. This paper is a product of the project "A consistent approach to groundwater recharge and discharge estimation in data poor areas" funded by the National Water Commission. The authors would like to thank, Tim Ellis and Don White for their 
helpful comments on this manuscript, and Fred Leaney, Ian Jolly, Phil Davies, Russel Crosbie and Laura Gow for input along the way. We would also like to thank Dale Worledge for his assistance drafting the figures.

Edited by: J. Liu

\section{References}

Baldocchi, D. D. and Meyers, T.: On using eco-physiological, micrometeorological and biogeochemical theory to evaluate carbon dioxide, water vapour and trace gas fluxes over vegetation: a perspective, Agr. Forest Meteorol., 90, 1-25, 1998.

Battaglia, M., Cherry, M. L., Beadle C. L., Sands, P. J., and Hingston, A.: Prediction of leaf area index in eucalypt plantations: effects of water stress and temperature, Tree Physiol., 18, 521-528, 1998.

Benyon, R. G. and Doody, T. M.: Water use by plantations in southeast South Australia, CSIRO Forestry and Forest Products, Mt Gambier Technical Report 148, 26, 30 pp., 2004.

Benyon, R. G., Theiveyanathan, S., and Doody, T. M.: Impacts of tree plantations on groundwater in south-eastern Australia, Aust. J. Bot., 54, 181-192, 2006.

Budyko, M. I.: Climate and Life, Academic, New York, 1974.

Carter, J. L. and White, D. A.: Plasticity in the Huber value contributes to homeostasis in leaf water relations of a mallee eucalypt with variation in depth to groundwater, Tree Physiol., 29, 1407-1418, 2009.

Crosbie, R. S., Wilson, B., Hughes, J. D., McCulloch, C., and King, W. M.: A comparison of the water use of tree belts and pasture in recharge and discharge zones in a saline catchment in the Central West of NSW, Australia, Agr. Water Manage., 95, 211-223, 2008.

Crosbie, R. S., Jolly, I. D., Leaney, F. W., and Petheram, C.: Can the dataset of field based recharge estimates in Australia be used to predict recharge in data-poor areas?, Hydrol. Earth Syst. Sci., 14, 2023-2038, doi:10.5194/hess-14-2023-2010, 2010.

Do, F. C., Rocheteau, A., Diagne, A. L., Goudiaby, V., Granier, A., and Homme, J.-P.: Stable annual pattern of water use by Acacia tortillus in Sahelian Africa, Tree Physiol., 28, 95-104, 2008.

Dodd, J. and Bell, D. T.: Water relations of the canopy species in a Banksia woodland, Swan Coastal Plain, Western Australia, Aust. J. Ecol., 18, 281-293, 1993.

Donohue, R. J., Roderick, M. L., and McVicar, T. R.: On the importance of including vegetation dynamics in Budyko's hydrological model, Hydrol. Earth Syst. Sci., 11, 983-995, doi:10.5194/hess11-983-2007, 2007.

Donohue, R. J., McVicar, T. M., and Roderick, M. L.: Climaterelated trends in Australian vegetation cover as inferred from satellite observations, Glob. Change Biol., 15, 1025-1039, 2009.

Donohue, R. J., McVicar, T. M., and Roderick, M. L.: Assessing the ability of potential evaporation formulations to capture the dynamics in evaporative demand within a changing climate, J. Hydrol., 390, 23-34, 2010.

Doody, T. M., Holland, K. L., Benyon, R. G., and Jolly, I. D.: Effect of groundwater freshening on riparian vegetation water balance, Hydrol. Process., 23, 3485-3499, 2009.

Drake, P. L. and Franks, P. J.: Water resource partitioning, stem xylem hydraulic properties, and plant water use strategies in a seasonally dry riparian tropical rainforest, Oecologia, 137, 321329, 2003.

Eagleson, P. S.: Climate, soil and vegetation 1. Introduction to water balance dynamics, Water Resour. Res., 14, 705-712, 1978.

Eagleson, P. S.: Ecological optimality in water limited natural soilvegetation systems 1 . theory and hypotheses, Water Resour. Res., 18, 325-340, 1982.

Eagleson, P. S. and Tellers, T. B.: Ecological optimality in waterlimited natural soil-vegetation systems 2. Tests and Applications, Water Resour. Res., 18, 2, doi:10.1029/WR018i002p00341, 1982.

Eamus, D.: How does ecosystem water balance affect net primary productivity of woody ecosystems? Funct. Plant Biol., 30, 187205, 2003.

Eamus, D. and Froend, R.: Groundwater-dependent ecosystems: the where, what and why of GDEs, Aust. J. Bot., 54, 91-96, 2006.

Eamus, D., O'Grady, A. P., and Hutley, L. B.: Dry season conditions determine wet season water use in the wet-dry tropical savannas of northern Australia, Tree Physiol., 20, 1219-1226, 2000.

Eamus, D., Hutley, L. B., and O'Grady, A. P.: Daily and seasonal patterns of carbon and water fluxes above a north Australian savanna, Tree Physiol., 21, 977-988, 2001.

Ellis, T. W. and Hatton, T. J.: Relating leaf area index of natural eucalypt vegetation to climate variables in southern Australia, Agr. Water Manage., 95, 743-747, 2008.

Ellis, T. W., Hatton, T., and Nuberg, I.: An ecological optimality approach for predicting deep drainage from tree belts of alley farms in water-limited environments, Agr. Water Manage., 75, 92-116, 2005.

Farrington, P., Greenwood, E. A. N., Bartle, G. A., Beresford, J. D., and Watson, G. D.: Evaporation from Banksia woodland on a groundwater mound, J. Hydrol., 105, 173-186, 1989.

Farrington, P., Watson, G. D., Bartle, G. A., and Greenwood, E. A. N.: Evaporation from dampland vegetation on a groundwater mound, J. Hydrol., 115, 65-75, 1990.

Grier, C. C. and Running, S. W.: Leaf area of mature northwestern coniferous forests-relation to site water balance, Ecology, 58, 893-899, 1977.

Groom, P. K., Froend, R. H. and Mattiske, E. M.: Impact of groundwater abstraction on a Banksia woodland, Swan Coastal Plain Western Australia, Ecol. Manage. Restor., 1, 117-124, 2000.

Guerschman, J. P., Van Dijk, A. I. J. M., Mattersdorf, G., Beringer, J., Hutley, L. B., Leuning, R., Pipunic, R. C., and Sherman, B. S.: Scaling of potential evapotranspiration with MODIS data reproduces flux observations and catchment water balance observations across Australia, J. Hydrol., 369, 107-119, 2009.

Hatton, T. J., Salvucci, G. D., and Wu, H. I.: Eaglesons optimality theory of an ecohydrological equilibrium: quo vadis?, Funct. Ecol., 11, 665-674, 1997.

Hill, M. J., Senarath, U., Lee, A., Zeppel, M., Nightingale, J. M., Williams, R. J., and McVicar, T. M.: Assessment of the MODIS LAI product for Australian Ecosystems, Remote Sens. Environ., 101, 495-518, 2006.

Holland, K. and Benyon, R.: Water use by Eucalyptus globulus plantations over shallow groundwater on the Fleurieu Peninsula, CSIRO Water for a Healthy Country National Research Flagship, 23 pp., 2011.

Hutley, L. B., Doley, D., Yates, D. J., and Boonsaner, A.: Water 
Balance of an Australian Subtropical Rainforest at Altitude: the Ecological and Physiological Significance of Intercepted Cloud and Fog, Aust. J. Bot., 45, 311-329, 1997.

Huxman, T. E., Smith, M. D., Fay, P. A., Knapp, A. K., Shaw, M. R., Loik, M. E., Smith, S. D., Tissue, D. T., Zak, J. C., Weltzin, J. F., Pockman, W. T., Sala, O. E., Haddad, B. M., Harte, J., Koch, G. W., Schwinning, S., Small, E. E., and Williams, D. G.: Convergence across biomes to a common rain-use efficiency, Nature, 429, 651-654, 2004.

Kerkhoff, A. J., Martens, S. N., and Milne, B. T.: An Ecological evaluation of Eagleson's optimality hypotheses, Funct. Ecol., 18, 404-413, 2004.

Lamontagne, S., Cook, P. G., O'Grady, A., and Eamus, D.: Groundwater use by vegetation in a tropical savanna riparian zone (Daly River, Australia), J. Hydrol., 310, 280-293, 2005.

Landsberg, J. J. and Waring, R. H.: A generalised model of forest productivity using simplified concepts of radiation use efficiency, carbon balance and partitioning, Forest Ecol. Manag., 95, 209228, 1997.

Liu, J.: A GIS-based tool for modelling large-scale crop-water relations, Environ. Modell. Softw., 24, 411-422, 2009.

Macfarlane, C., Lardner, T., Patterson, K., and Grigg, A. H.: A new model for predicting understorey leaf area from biomass in eucalypt forest to test the ecohydrological equilibrium theory, Method. Ecol. Evol. 1, 371-379, 2010.

McJannet, D., Wallace, J., Fitch, P., Disher, M., and Reddell, P.: Water balance of tropical rainforest canopies in north Queensland, Australia, Hydrol. Process., 21, 3473-3484, 2007.

Morris, J. D. and Collopy, J. J.: Water use and salt accumulation by Eucalyptus camaldulensis and Casuarina cunninghamiana on a site with shallow saline groundwater, Agr. Water Manage., 39, 205-227, 1999.

Nemani, R. R. and Running, S. W.: Testing a theoretical climatesoil-leaf area hydrological equilibrium of forests using satellite data and ecosystem simulation, Agr. Forest Meteorol., 44, 245260, 1989.

O’Grady, A. P., Eamus, D., Cook, P., Lamontange, S., Kelley, G., and Hutley, L.: Tree water use and sources of transpired water in riparian vegetation along the Daly River, Northern Territory, Northern Territory University, 157, 2002.

O'Grady, A. P., Worledge, D., and Battaglia, M.: Temporal and spatial changes in fine root distributions in a young Eucalyptus globulus stand in southern Tasmania, Forest Ecol. Manag., 214, 373-383, 2005.
O'Grady, A. P., Cook, P. G., Howe, P., and Werren, G.: Groundwater use by dominant tree species in tropical remnant vegetation communities, Aust. J. Bot., 54, 155-171, 2006.

O'Grady, A. P., Cook, P. G., Eamus, D., Duguid, A., Wischusen, J. D. H., Fass, T., and Worledge, D.: Convergence in water use within an arid-zone woodland, Oecologia, 160, 643-655, 2009.

Specht, R. L.: Water use by perennial evergreen plant communities in Australia and Papua New Guinea, Aust. J. Bot., 20, 273-299, 1972.

Specht, R. L.: Foliage projective covers of overstorey and understorey strata of mature vegetation in Australia, Aust. J. Ecol., 8, 433-439, 1983.

Specht, R. L. and Morgan, D. G.: The balance between the foliage projective covers of overstorey and understorey strata in Australian vegetation, Aust. J. Ecol., 6, 193-202, 1981.

Thorburn, P. J., Hatton, T. J., and Walker, G. R.: Combining measurements of transpiration and stable isotopes of water to determine groundwater discharge from forests, J. Hydrol., 150, 563587, 1993.

Warton, D. I., Wright, I. J., Falster, D. S., and Westoby, M.: Bivariate line fitting methods for allometry, Biol. Rev., 81, 259-291, 2006.

White, D. A., Dunnin, F. X., Turner, N. C., Ward, B. H., and Galbraith, J. H.: Water use by contour-planted belts of trees comprised of four species of eucalypts, Agri. Water Manage., 53, 133-152, 2002.

White, D. A., Battaglia, M., Mendham, D. S., Crombie, D. S., Kinal, J., and McGrath, J. F.: Observed and modelled leaf area index in Eucalyptus globulus plantations: tests of optimality and equilibrium hypotheses, Tree Physiol., 30, 831-844, 2010.

Wildy, D. T., Pate, J. S., and Bartle, J. R.: Budgets of water use by Eucalyptus kochii tree belts in the semi-arid wheatbelt of Western Australia, Plant Soil, 262, 129-149, 2004.

Zhang, L., Hickel, K., Dawes, W. R., Chiew, F. H. S., Western, A. W., and Briggs, P. R.: A rational function approach for estimating mean annual evapotranspiration, Water Resour. Res., 40, W02502, doi:10.1029/2003WR002710, 2004.

Zhang, L., Potter, N., Hickel, K., Zhang, Y., and Shao, Q.: Water balance modelling over variable time scales based on the Budyko framework-model development and testing, J. Hydrol., 360, 117131, 2008. 